\title{
New records of marine tardigrades from Brazil
}

\author{
Clélia Márcia CAVALCANTI DA ROCHA, ${ }^{1 *}$ Érika CAVALCANTE LEITE DOS SANTOS, ${ }^{1}$ Edivaldo LIMA GOMES \\ JÚNIOR, ${ }^{1,2}$ Juliana DA ROCHA MOURA, ${ }^{2}$ Luíza Gabriela SANTANA e SILVA, ${ }^{1}$ Débora FERREIRA BARBOSA ${ }^{1}$
}

${ }^{1}$ Departamento de Biologia, Universidade Federal Rural de Pernambuco, Avenida Manoel de Medeiros, 52171-900 Recife, Pernambuco; ${ }^{2}$ Conselho Nacional de Desenvolvimento Científico e Tecnológico, Shis Qi 1 Área Especial s/n, 71605-001 Brasília, Brazil *Corresponding author: clelia@db.ufrpe.br

\begin{abstract}
In studies developed in the mid-and infralittoral of Cupe beach (Pernambuco), in the shallow infralittoral of Saint Peter and Saint Paul archipelago, and in the continental shelf of Northeastern Brazil, we recorded for the first time in Brazilian waters specimens of Archechiniscus marci, Batillipes lesteri, Florarctus hulingsi, Halechiniscus tuleari, Angursa lingua, Raiarctus aureolatus, Actinarctus doryphorus doryphorus, Tanarctus dendriticus, Tanarctus velatus, Neoarctus $s p$. and Neostygarctus $s p$., as well as six other species that had been previously recorded in the region. Hence, the number of marine tardigrade taxa recorded in Brazil was increased to twenty-seven.
\end{abstract}

Key words: Tardigrada, Batillipedidae, Halechiniscidae, Stygarctidae, Neostygarctidae, Neoarctidae.

\section{INTRODUCTION}

Taxonomic information about marine tardigrades in Brazil is currently restricted to the studies by Marcus (1946), Bois-Reymond Marcus (1952), HöflingEpiphanio (1972), Renaud-Mornant (1980, 1984, 1990), Da Rocha et al. (2009) and Moura et al. (2009). Marcus (1946) described a new genus, Batillipes (from São Paulo), and Bois-Reymond Marcus (1952) described the genus Orzeliscus (from São Paulo). Renaud-Mornant $(1980,1984,1990)$ described a new species, Tanarctus heterodactylus Renaud-Mornant, 1980 (from Rio de Janeiro) and two new genera, Chrysoarctus (from Rio de Janeiro) and Opydorscus (from the northern continental shelf of Brazil).

Until 2006 only eight species were known for Brazil: Batillipes pennaki Marcus, 1946, Batillipes mirus Richters, 1908, Batillipes tubernatis Pollock, 1970, Chrysoarctus briandi Renaud-Mornant, 1984, Orzeliscus belopus Marcus, 1952, Opydorscus fonsecae RenaudMornant, 1990, Tanarctus heterodactylus and Echiniscoides sigismundi Schultze, 1865.

Da Rocha et al. (2009) recorded six other species in northeastern Brazil (Pernambuco), and Moura et al. (2009) recorded two other species also in northeastern Brazil (Saint Peter and Saint Paul archipelago).

In this study, we present the results of studies carried out on Cupe beach (Ipojuca, state of Pernambuco), in Saint Peter and Saint Paul archipelago (state of Rio Grande do Norte), and in the continental shelf of the states of Ceará and Rio Grande do Norte (Fig. 1). Seventeen species were recorded, of which 11 are new records for Brazil. The geographic range of some species, such as Neostygarctus sp. and Neoarctus sp., was previously assumed to be much more restricted (to Mediterranean sea). Other species such as Batillipes lesteri Kristensen and Mackness, $2000 \mathrm{An}$ gursa lingua Bussau, 1992, Tanarctus dendriticus RenaudMornant, 1980, and T. velatus had already been recorded outside their type localities. With the present study, there are 27 marine tardigrade species in Brazil.

\section{METHODS}

Cupe beach (Pernambuco, Brazil) is located between the coordinates $8^{\circ} 25^{\prime} 10^{\prime \prime} / 8^{\circ} 25^{\prime} 20^{\prime \prime} \mathrm{S}$ and $34^{\circ} 55^{\prime} 00^{\prime \prime} \mathrm{W}$, and is characterized by a barrier of sandstone reefs with many natural pools where organic gravel or sandy-muddy sediments are deposited (Da Rocha et al., 2009). Saint Peter and Saint Paul archipelago is a remote group of islands close to the Equator, in the Northern Hemisphere $\left(00^{\circ} 56^{\prime} \mathrm{N} ; 29^{\circ} 22^{\prime} \mathrm{W}\right), c a .1100 \mathrm{~km}$ distant from the city of Natal (Rio Grande do Norte, Brazil) (Amaral et al., 2009). The continental shelf of the states of Ceará and Rio Grande do Norte $\left(4^{\circ} 20^{\prime} / 4^{\circ} 50^{\prime} \mathrm{S} ; 36^{\circ} 00^{\prime} / 37^{\circ} 15^{\prime} \mathrm{W}\right)$ has sediments that vary from fine to coarse quartz sands, or quartz sands with detritus, and terrigenous muds.

On Cupe beach, we carried out sampling in the shallow infralittoral and in the intertidal zone, using PVC cylinder (corer) with $10 \mathrm{~cm}^{2}$ of internal area, as described by Higgins and Thiel (1988). In the Saint Peter and Saint Paul archipelago we also carried out collections with a PVC corer, through scuba diving at 3 to $11 \mathrm{~m}$ depth. In the continental 
shelf of the states of Ceará and Rio Grande do Norte we sampled at 20 to $100 \mathrm{~m}$ depth using a box corer.

The samples were treated according to routine techniques for meiofauna (humid sieving and manual centrifugation) following Elmgren (1966), and sorted out using Dollfus plates under stereoscopic microscope. The tardigrades were removed manually using a stainless steel forceps, and permanent slides were made by techniques proposed by Cobb (1917) and Renaud-Debyser and Salvat (1963). We identified tardigrades under a microscope (Olympus CX 31), using a pictorial key by Ramazzotti and Maucci (1983) and original descriptions of species. Microphotographs were made using a digital camera (Olympus C-5050 Zoom).

The results are presented following the order proposed by Degma et al. (2009-2012).

\section{RESULTS}

Class: HETEROTARDIGRADA Marcus, 1927. Order: ARTHROTARDIGRADA Marcus, 1927.
Family: Archechiniscidae Binda, 1978.

Genus: Archechiniscus Schultz, 1953.

Species: Archechiniscus marci Schulz, 1953.

Material examined: Seventy-three specimens collected from the continental shelf of the states of Ceará and Rio Grande do Norte.

Distribution: El Salvador (Schulz, 1953), New Caledonia (Renaud-Mornant, 1967), Bahamas, and Galapagos islands (Schuster and Grigarick, 1966).

Ecological notes: Found in coarse quartz sands at $20 \mathrm{~m}$ depth and terrigenous muds at $100 \mathrm{~m}$ depth.

Family: Batillipedidae Richters, 1909.

Genus: Batillipes Richters, 1909.

Species: Batillipes lesteri Kristensen and Mackness, 2000.

Material examined: Ten specimens collected on Cupe beach (Pernambuco, Brazil) and 52 specimens collected from the continental shelf of the states of Ceará and Rio Grande do Norte.

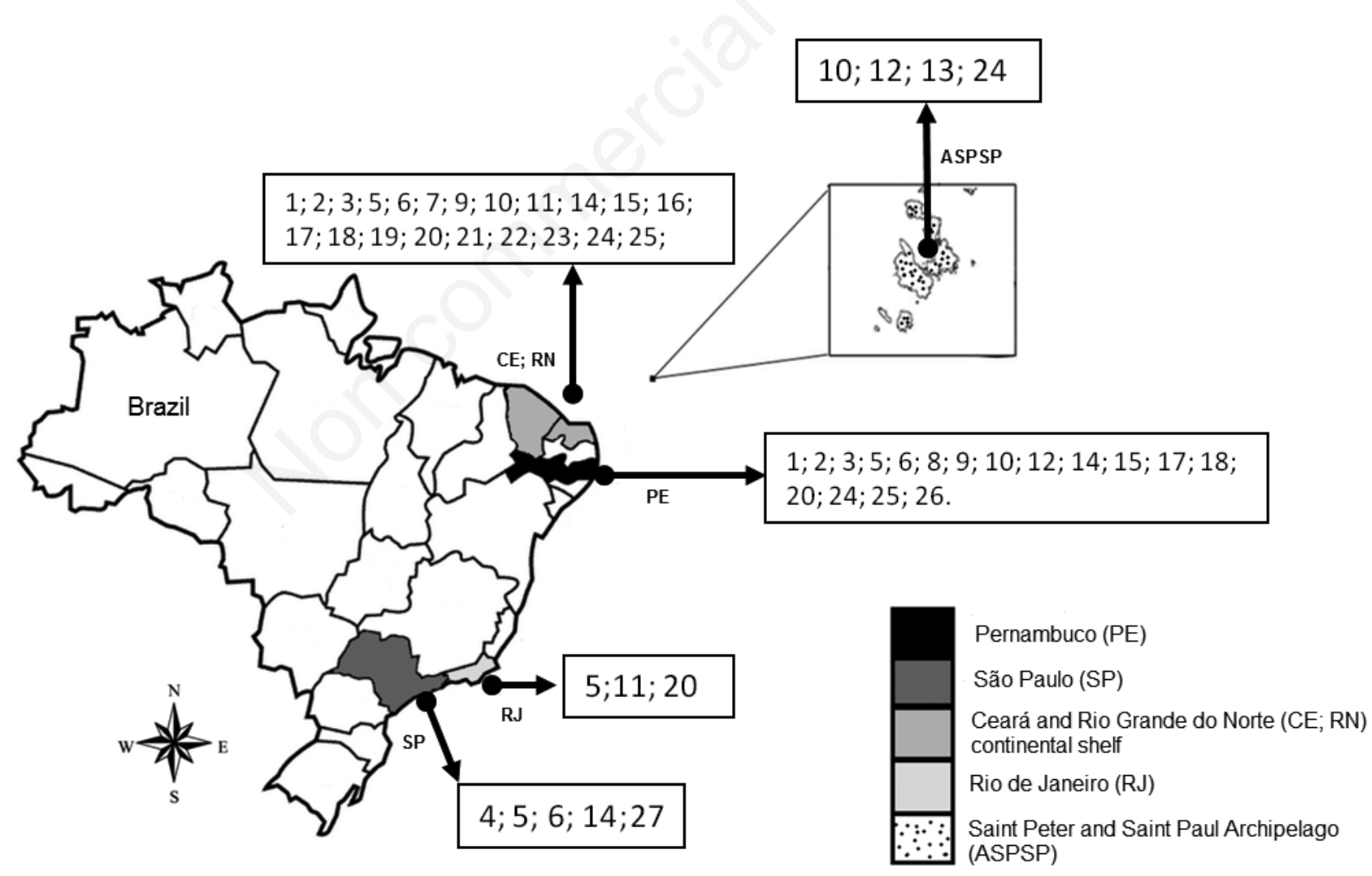

Fig. 1. Distribution of marine tardigrades species in Brazil, 1, Batillipes annulatus; 2, Batillipes dicrocercus; 3, Batillipes lesteri; 4, Batillipes mirus; 5, Batillipes pennaki; 6, Batillipes tubernatis; 7, Archechiniscus marci; 8, Dipodarctus subterraneus; 9, Florarctus hulingsi; 10, Wingstrandarctus intermedius; 11, Chrysoarctus briandi; 12, Halechiniscus perfectus; 13, Halechiniscus tuleari; 14, Orzeliscus belopus; 15, Opydorscus fonsecae; 16, Angursa lingua; 17, Raiarctus aureolatus; 18, Actinarctus doryphorus doryphorus; 19, Tanarctus dendriticus; 20, Tanarctus heterodactylus; 21, Tanarctus velatus; 22, Neoarctus sp.; 23, Neostygarctus sp.; 24, Parastygarctus sterreri; 25, Pseudostygarctus intermedius; 26, Stygarctus bradypus; 27, Echiniscoides sigismundi. 
Distribution: Australia (Kristensen and Mackness, 2000).

Ecological notes: Found in the midlittoral in medium to fine quartz sands on Cupe beach and in medium sands at $35 \mathrm{~m}$ depth in the continental shelf of the states of Ceará and Rio Grande do Norte.

Family: Halechiniscidae Thulin, 1928.

Sub-family: Florarctinae Renaud-Mornant, 1982. Genus: Florarctus Delamare Deboutteville and Renaud-Mornant, 1965.

Species: Florarctus hulingsi Renaud-Mornant, 1976.

Material examined: Twenty specimens collected on Cupe beach and 90 specimens collected from the continental shelf of the states of Ceará and Rio Grande do Norte.

Distribution: Italy, Malta, France, Alboran sea, Morocco, Tunisia, Algeria, Mauritius islands, Madagascar (De Zio Grimaldi et al., 2003), Seychelles islands, Maldive islands (Gallo et al., 2007) and Iberian peninsula (Guil, 2002).

Ecological notes: Found in the shallow infralittoral in biogenic gravels at $3 \mathrm{~m}$ depth in Saint Peter and Saint Paul archipelago and in coarse quartz sands at $20 \mathrm{~m}$ depth in the continental shelf of the states of Ceará and Rio Grande do Norte.

Sub-family: Halechiniscinae Thulin, 1928. Genus: Halechiniscus Richters, 1908.

Species: Halechiniscus tuleari RenaudMornant, 1979.

Material examined: Sixty-four specimens collected in Saint Peter and Saint Paul archipelago.

Distribution: Italy, Malta, Madagascar (De Zio Grimaldi et al., 2003) and Indian ocean (Gallo et al., 2007).

Ecological notes: Found in biogenic gravels at $11 \mathrm{~m}$ depth.

Sub-family: Styraconixinae Kristensen and Renaud-Mornant, 1983.

Genus: Angursa Pollock, 1979.

Species: Angursa lingua Bussau, 1992.

Material examined: One hundred and four specimens collected from the continental shelf of the states of Ceara and Rio Grande do Norte.

Distribution: Peru (Bussau, 1992).

Ecological notes: Found in coarse quartz sands at $20 \mathrm{~m}$ depth and terrigenous muds at $100 \mathrm{~m}$ depth.

Genus: Raiarctus Renaud-Mornant, 1981.

Species: Raiarctus aureolatus RenaudMornant, 1981.

Material examined: Ninety-six specimens collected from the continental shelf of the states of Ceará and Rio Grande do Norte.
Distribution: France, Madagascar, Italy, Faroe islands and the USA (De Zio Grimaldi et al., 2003).

Ecological notes: Found in coarse quartz sands at $20 \mathrm{~m}$ depth and terrigenous muds at $100 \mathrm{~m}$ depth.

Sub-family: Tanarctinae Renaud-Mornant, 1980

Genus: Actinarctus Schultz, 1935.

Species: Actinarctus doryphorus doryphorus Schulz, 1935.

Material examined: Two specimens recorded on Cupe beach and 36 specimens recorded from the continental shelf of the states of Ceará and Rio Grande do Norte.

Distribution: Germany, Denmark, Italy, Alboran sea and France (De Zio Grimaldi et al, 2003).

Ecological notes: Found in biogenic gravels at $3 \mathrm{~m}$ depth on Cupe beach and in coarse quartz sands at $20 \mathrm{~m}$ depth in the continental shelf of the states of Ceará and Rio Grande do Norte.

Genus: Tanarctus Renaud-Debyser, 1959. Species: Tanarctus dendriticus RenaudMornant, 1980.

Material examined: A single specimen recorded from the continental shelf of the states of Ceará and Rio Grande do Norte.

Distribution: USA (Renaud-Mornant, 1980).

Ecological notes: Found in terrigenous muds at $100 \mathrm{~m}$ depth.

Species: Tanarctus velatus McKirdy, Schmidt and McGinty-Bayly, 1976.

Material examined: Three specimens collected from the continental shelf of the states of Ceará and Rio Grande do Norte.

Distribution: Galapagos islands (McKirdy et al., 1976).

Ecological notes: Found in coarse quartz sands at $20 \mathrm{~m}$ depth and terrigenous muds at $100 \mathrm{~m}$ depth.

Family: Neoarctidae Grimaldi de Zio, D’Addabbo Gallo and Morone De Lucia, 1992.

Genus: Neoarctus Grimaldi de Zio, D’Addabbo Gallo and Morone De Lucia, 1992.

Material examined: A single specimen collected from the continental shelf of the states of Ceará and Rio Grande do Norte (Fig. 2).

Distribution: Mediterranean sea - Italy (De Zio Grimaldi et al., 2003).

Ecological notes: Found in terrigenous muds at $100 \mathrm{~m}$ depth.

Family: Neostygarctidae Grimaldi de Zio, D'Addabbo Gallo and Morone De Lucia, 1987.

Genus: Neostygarctus Grimaldi de Zio,

D’Addabbo Gallo and Morone De Lucia, 1982.

Material examined: A single specimen at larval stage col- 
lected from the continental shelf of the states of Ceará and Rio Grande do Norte (Fig. 3).

Distribution: Mediterranean sea - Italy and Spain (De Zio Grimaldi et al., 2003).

Ecological notes: Found in terrigenous muds at $100 \mathrm{~m}$ depth.

Other species of the families Halechiniscidae and Stygarctidae, whose presence has already been reported in Brazilian waters, had their geographic range extended in the present study: Chrysoarctus briandi Renaud-Mornant, 1984, Orzeliscus belopus Bois-Reymond Marcus, 1952, Opydorscus fonsecae Renaud-Mornant, 1990, Tanarctus heterodactylus, Parastygarctus sterreri Renaud-Mornant, 1970 and Pseudostygarctus intermedius Renaud-Mornant, 1979 (Tab. 1).

\section{DISCUSSION}

Hence, the number of marine tardigrade taxa recorded in Brazilian waters increased to 27: A. marci, B. annulatus, $B$. dicrocercus, B. lesteri, B. mirus, B. pennaki, B. tubernatis, D. subterraneus, $F$. hulingsi, $W$. intermedius, $C$. briandi, $H$. perfectus, $H$. tuleari, O. belopus, O. fonsecae, A. lingua, R. aureolatus, A. doryphorus doryphorus, T. dendriticus, T. heterodactylus, T. velatus, Neoarctus sp.,

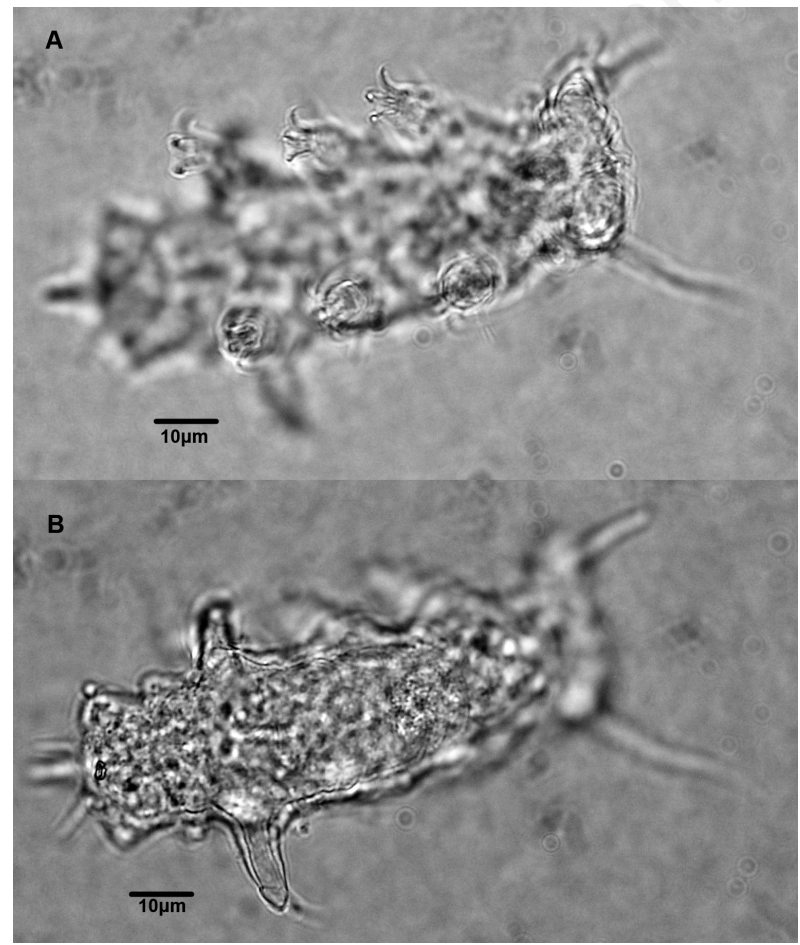

Fig. 2. A-B. Neoarctus sp. found in the continental shelf of the states of Ceará and Rio Grande do Norte (Brazil).
Neostygarctus sp., P. sterreri, P. intermedius, S. bradypus and $E$. sigismundi.

Some of the species reported here were recorded for the first time in the Southern Hemisphere (A. doryphorus doryphorus, T. dendriticus, Neostygarctus sp., Neoarctus sp.) or the Atlantic ocean (A marci, B. lesteri, A. lingua, T. velatus, Neostygarctus sp., Neoarctus sp.).

The taxa considered rare, Neoarctus and Neostygarctus sp., were recorded for the first time outside the Mediterranean sea in the present study (Fig. 4); the same is true for $B$. lesteri, which was previously found only in Australia; A. lingua, recorded only in an area of manganese nodules in an abyssal region of Peru; T. dendriticus, recorded only in the USA; and T. velatus, recorded only on the Galapagos islands.

\section{CONCLUSIONS}

Based on the previous records of these species, the present study significantly advanced the knowledge of their biogeography. These results point to the need for further taxonomic studies on marine tardigrades. Considering mainly the record of Neoarctus and Neostygarctus in a region far from their assumed occurrence area, we conclude that future studies on these taxa could result in interesting findings and advance the knowledge of tardigrades.

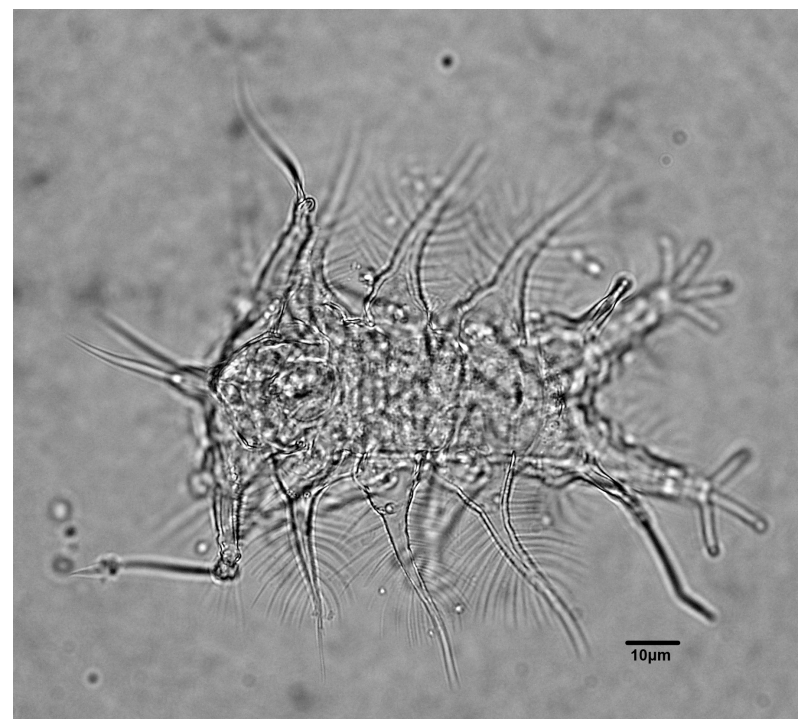

Fig. 3. Neostygarctus sp. (larva) found in the continental shelf of the states of Ceará and Rio Grande do Norte (Brazil). 


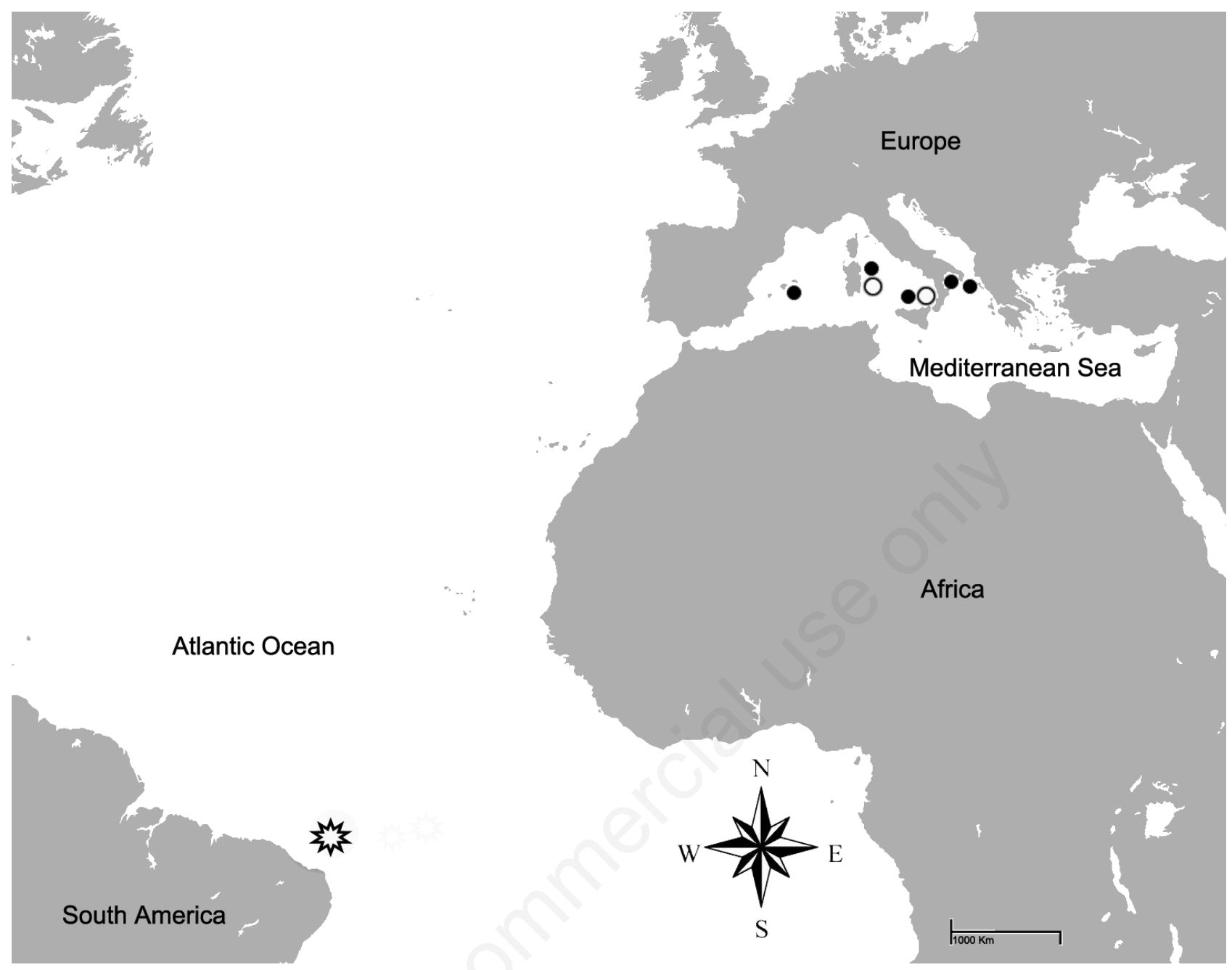

Fig. 4. Geographic range of Neostygarctus sp. and Neoarctidae. $\bullet=$ Neostygarctus sp. previous records; o=Neoarctus sp. previous records; 米 $=$ new records in Brazil.

Tab. 1. Species of marine tardigrades with previously recorded occurrence in Brazil, with extended geographical distribution.

\begin{tabular}{lcr}
\hline Species & Previous registration & Current registration \\
\hline Orzeliscus belopus Bois-Reymond Marcus, 1952 & Sao Paulo (Brazil) & Cupe beach (PE) and continental shelf of the Northeast of Brazil \\
\hline Chrysoarctus briandi Renaud-Mornant, 1984 & Rio de Janeiro (Brazil) & Continental shelf of the Northeast of Brazil \\
\hline $\begin{array}{l}\text { Opydorscus fonsecae } \text { Renaud-Mornant, 1990 } \\
\text { Tanarctus heterodactylus Renaud-Mornant, 1980 }\end{array}$ & Ceara (Brazil) & $\begin{array}{c}\text { Itamaraca island (PE) and continental shelf of the Northeast } \\
\text { of Brazil }\end{array}$ \\
\hline Parastygarctus sterreri Renaud-Mornant, 1970 & St. Peter and St. Paul archipelago & Cupe beach and continental shelf of the Northeast of Brazil \\
& (Brazil) & Continental shelf of the Northeast of Brazil \\
\hline Pseudostygarctus intermedius Renaud-Mornant, 1979 & PE (Brazil) & Ceach and continental shelf of the Northeast of Brazil \\
\hline PE Pernambuco & &
\end{tabular}




\section{ACNOWLEDGMENTS}

We thank the Conselho Nacional de Desenvolvimento Científico e Tecnológico (Brazilian government) for granting us an undergraduate scholarship, the Brazilian Navy for the transport to the Saint Peter and Saint Paul archipelago, PETROBRAS (Petróleo Brasileiro S/A) for allowing us to collect in the continental shelf of N/NE, and Dr. Alessandra P. Botelho for making the images. We thank the reviewers for correcting an early version of the manuscript and improving the English grammar, especially Paul Bartels.

\section{REFERENCES}

Amaral FD, Da Rocha CMC, Farrapeira CMR, Alves MS, Pinto SL, Lira SMA, Melo KK, Ramos CAC, Dos Santos ECL, Moura JR, Oliveira DAS, Verçosa MM, Melo AVM, Oliveira APA, Gonçalves EF, 2009. [Distribuição espacial de invertebrados bentônicos infralitorais], p. 126-134. In: Secretaria da Comissão Interministerial para os Recursos do Mar (ed.), [O Arquipélago de São Pedro e São Paulo: 10 anos de Estação Científica]. [Book in Portuguese]. SECIRM ed.

Bois-Reymond Marcus ED, 1952. On South American Malacopoda. Biol. Fac. Fil. Cien. Letr. S. Paulo Zoologica 17:189-209.

Bussau C, 1992. New deep-sea Tardigrada (Arthrotardigrada, Halechiniscidae) from manganese nodule area of the eastern South Pacific. Zool. Scr. 21:79-91.

Cobb NA, 1917. Note on nemas. Contr. Sci. Nematol. 5:117128.

Da Rocha CMC, Verçosa MM, Dos Santos ECL, Barbosa DF, Oliveira DAS, Souza JRB, 2009. Marine tardigrades from the coast of Pernambuco, Brazil. Meiofauna Marina 17:97-101.

Degma P., Bertolani R, Guidetti R, 2009-2012. Actual checklist of Tardigrada species (2009-2012, Ver. 21: 30-06-2012). Available from: www.tardigrada.modena.unimo.it/miscellanea/Actual checklist of Tardigrada.pdf Accessed: 10 Oct. 2012.

De Zio Grimaldi S, Gallo D'Addabo M, Sandulli R, D'Addabo $\mathrm{R}, 2003$. Checklist of the Italian marine Tardigrada. Meiofauna Mar. 12:97-135.

Elmgren R, 1966. Methods of sampling sublittoral soft bottom meiofauna. Oikos(Suppl. 15):112-120.

Gallo M, D'Addabbo R, De Leonardis C, Sandulli R, De Zio Grimaldi S, 2007. The diversity of Indian ocean Heterotardigrada. J. Limnol. 66(Suppl. 1):60-64.

Guil N, 2002. Diversity and distribution of tardigrades (Bilateria, Tardigrada) from the Iberian peninsula, Balearic islands and Chafarinas islands. Graellsia 58:75-94.
Higgins RP, Thiel H, 1988. Introduction to the study of meiofauna. First edition. Smithsonian Institution Press, Washington D.C.: 488 pp.

Höfling-Epiphanio E, 1972. [Ocorrência de Batillipes mirus Richters, 1909 e B. tubernatis Pollock, 1971 (Tardigrada) no litoral brasileiro]. [Article in Portuguese]. Ciência e Cultura 24:358-359.

Kristensen RM, Mackness BS, 2000. First record of the marine tardigrade genus Batillipes (Arthrotardigrada: Batillipedidae) from South Australia with a description of a new species. Rec. South Austral. Mus. 33:73-87.

Marcus E, 1946. Batillipes pennaki, a new marine Tardigrada from the North and South American Coast. Com. Zool. Mus. Hist. Nat. Montevideo 2:1-3.

Mckirdy D, Schmidt P, Mc-Ginty-Bayly M, 1976. Interstitielle Fauna von Galapagos XVI. Tardigrada. Mikrof. Meeresb. 58:409-449.

Moura JR, Verçosa MM, Santos ECL, Silva LGS, Amaral FMD, Da Rocha CMC, 2009. [Ocorrência de Parastygarctus sterreri Renaut-Mornant, 1970 e Halechiniscus perfectus Schulz, 1955 (Tardigrada, Heterotardigrada) no Arquipélago São Pedro São Paulo, RN, Brasil]. [Article in Portuguese]. Atlântica 31:213-216.

Ramazzotti G, Maucci W, 1983. [II Phylum Tardigrada. Terza edizione riveduta e corretta]. [Article in Italian]. Mem. Inst. Ital. Idrobiol. 41:13-1012.

Renaud-Debyser J, Salvat B, 1963. [Récherches ecologiques sur la faune interstitielle des sables. Bassin d'Arcachon. Île de Bikini, Bahamas]. [Article in French]. Vie et Millieu 14:465550.

Renaud-Mornant J, 1980. [Description de trois espèces nouvelles du genre Tanarctus Renaud-Debyser, 1959 et création de la sous-famille des Tanarctinae, subfam. nov. (Tardigrada, Heterotardigrada)]. [Article in French]. Bull. Mus. Natn. Hist. Nat. Paris, Sér. $4^{e}$ Sect. A 2:129-141.

Renaud-Mornant J, 1984. [Halechiniscidae (Heterotardigrada) de la campagne Benthedi, canal du Mozambique]. [Article in French]. Bull. Mus. Natn. Hist. Nat. Paris, Sér. $4^{\mathrm{e}}$ Sect. A 6:67-88.

Renaud-Mornant J, 1990. [Opydorscus, un nouveau genre d'Orzeliniscinae et sa signification phylogenique (Tardigrada, Arthrotardigrada)]. [Article in French]. Bull. Mus. Natn. Hist. Nat. Paris, Sér. $4^{\text {e }}$ Sect. A 4:763-771.

Schulz E, 1953. [Eine neue Tardigraden-Gattung von der pazifischen Küste]. [Article in German]. Zool. Anz., 151:306310 .

Schuster RO, Grigarick AA, 1966. Tardigrada from the Galapagos and Cocos islands. Proc. Calif. Acad. Sci. 34:315-328. 